\title{
Chop-Leach Fuel Bundle Residues Densification by Melting
}

November 1976

Prepared for the Energy Research and Development Administration under Contract E(45-1)-1830 
NOTICE

This report was prepared as an account of work sponsored by the United States Government. Neither the United States nor the Energy Research and Development Administration, nor any of their employees, nor any of their contractors, subcontractors, or their employees, makes any warranty, express or implied, or assumes any legal !iability or responsibility for the accuracy, completeness or usefulness of any imformation, apparatus, product or process disclosed, or represents that its use would not infringe privately owned rights.

PACIFIC NORTHWEST LABORATORY

operated by

BATTELLE

for the

ENERGY RESEARCH AND DEVELOPMENT ADMINISTRATION

Under Contract E(45-1)-1830

\author{
Printed in the United States of America \\ Available from \\ National Technical Information Service \\ U.S. Department of Commerce \\ 5285 Port Royal Road \\ Springfield, Virginia 22151
}

Price: Printed Copy \$4.50; Microfiche \$2.25 
BNWL -2132

UC-70

33679000627184

CHOP-LEACH FUEL BUNDLE RESIDUES

DENSIFICATION BY MELTING

by

R. G. Nelson

B. Griggs

November 1976

Battelle

Pacific Northwest Laboratories

Richland, Washington 99352 
. 


\section{SUMMARY}

Two melting processes were investigated for the densification of fuel bundle residues: Industoslag melting and graphite crucible melting. The Industoslag process, with prior decontamination and sorting, can produce ingots of Zircaloy, stainless steel and Inconel of a quality suitable for refabrication and reuse. The process can also melt oxidized mixtures of fuel bundle residues for direct storage. Eutectic mixtures of these materials can be melted in graphite at temperatures of $1300^{\circ} \mathrm{C}$. Hydrogen absorption experiments with the zirconium-rich alloys show the alloys to be potential tritium reservoirs. 


\section{CONTENTS}

SUMMARY

LIST OF FIGURES $\quad$ •

INTRODUCTION

DESCRIPTION OF THE CHOP-LEACH FUEL BUNDLE RESIDUES • • • • • 1

CONCLUSIONS $\quad$ •

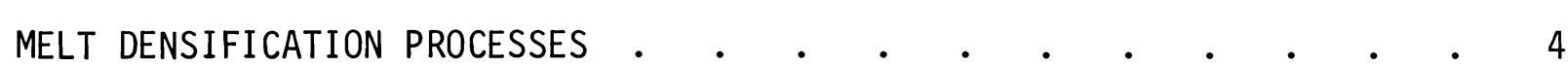

INDUCTOSLAG MELTING $\quad$ • $\quad$ •

GRAPHITE CRUCIBLE MELTING $\quad$ • $\quad$ •

TRITIUM ABSORPTION AND STORAGE IN ZIRCONIUM ALLOY INGOTS • • • 22

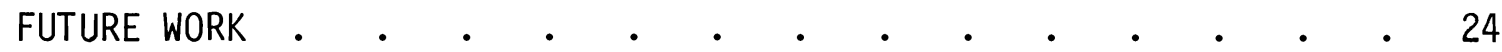

REFERENCES •

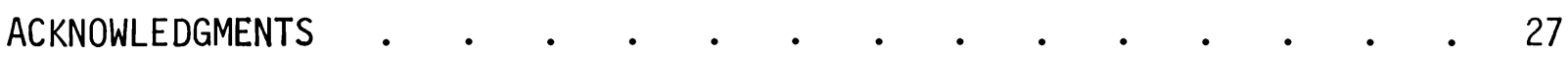




\section{LIST OF FIGURES}

1 Inductoslag Melting Process . . . . . . . . . . . 6

2 Inductoslag Remelted Chopped Leached Cladding Hul1s, Zircaloy-4 . 7

3 Transverse Sections of $10 \mathrm{~cm}$ Diameter Inductoslag Ingot . . 9

4 0xidized Zircaloy-4 Melted by Inductoslag USBM 529 . . . . 10

5 Oxidized Zircaloy, Stainless Steel, Inconel Alloys Melted by Inductoslag USBM 534 .

6 Oxidized Mixtures of Zircaloy-4 with Inconel 718 and 304 Stainless Steel Melted by Inductoslag . . . . . . . 13

7 Binary Equilibrium Diagrams of Zirconium with Iron, Nickel and Chromium . . . . . . . . . . . . . . 14

885 wt\% Zircaloy-2, 10 wt\% 304L Stainless Steel, . . . . . 16

980 wt\% Zircaloy-2, 13.4 wt\% 304L Stainless Steel,

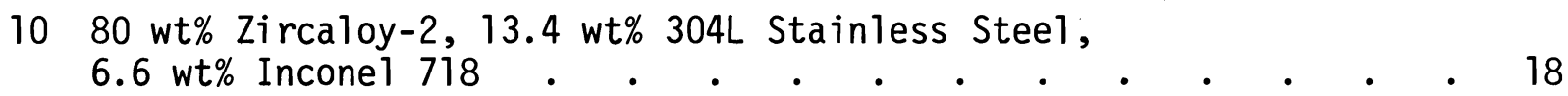

$1190 \mathrm{wt} \%$ Zircaloy-2, $6.7 \mathrm{wt} \%$ 304L Stainless Steel,

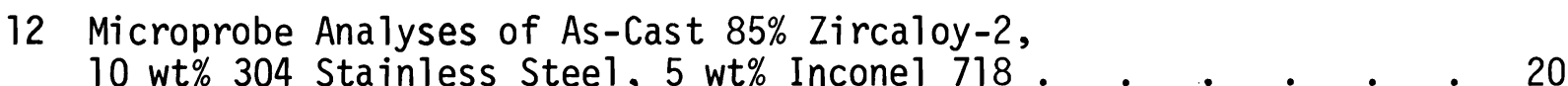

13 Hydrogen Pressure Versus Time at $700^{\circ} \mathrm{C}$. . . . . . 23 


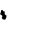


CHOP-LEACH FUEL BUNDLE RESIDUES

DENSIFICATION BY MELTING

\section{INTRODUCTION}

In current LWR fuel reprocessing technology, fuel bundles are sheared in short lengths for acid leach of the fuel pellets. The residues from the acid leach include short lengths of fuel cladding, massive end fittings, fuel spacer grids, assorted springs, guide thimbles and flow channels. These residues constitute a high volume waste, amounting in weight to about $22 \%$ of the fuel bundle. Without densification they constitute a substantially higher volume than the high level transuranic (TRU) calcines or glasses. Densification by melting will reduce this volume by a factor of 6 . These materials have a bulk density of about $1.1 \mathrm{~kg} / \mathrm{l}$. As recovered from the dissolver these hardware residues represent about $325 \mathrm{~kg} / \mathrm{MT}$ of uranium, and consist of 70 to $80 \mathrm{wt} \%$ Zircaloy, 12 to $22 \mathrm{wt} \%$ stainless steel (SS) and 8 wt\% Inconel.

PNL is evaluating the decontamination and melt densification of the chop-leach fuel bundle residues to minimize waste storage. Decontamination of the residues prior to melting to remove TRU element contamination is being developed to qualify the treated metals for simpler, less expensive waste disposal categories. The results of two melting processes for the densification of unirradiated fuel bundle hardware materials will be discussed in the following text.

\section{DESCRIPTION OF THE CHOP-LEACH FUEL BUNDLE RESIDUES}

The head end of the fuel reprocessing stream consists of short pieces of fuel element cladding together with the end hardware and spacers, etc., which have been neutron irradiated. The principal activation products remaining in the Zircaloy after 5 and 100 years cooling, as calculated by ORIGEN code, are: ${ }^{60} \mathrm{Co},{ }^{55} \mathrm{Fe},{ }^{125} \mathrm{Sb},{ }^{63} \mathrm{Ni}$, and ${ }^{125 \mathrm{~m}_{\mathrm{Te}}}$. The total activity is $900 \mu \mathrm{Ci} / \mathrm{g}$ zirconium $(\mathrm{Zr})$ after 5 years and $18 \mu \mathrm{Ci} / \mathrm{g}$ after 100 years. 
Zircaloy-2 and -4 usually contain trace uranium ( $1 \mathrm{ppm}$ ) which will transmute to TRU elements or fission during the irradiation. Calculations by ORIGEN code of the expected TRU contamination, uniformly dispersed in the metal from $1 \mathrm{ppm}$ natural uranium contamination (irradiated in a typical fuel exposure), indicate the principal isotopes would be about $85 \mathrm{nCi} / \mathrm{g}$ of ${ }^{241} \mathrm{Pu}$ and $2 \mathrm{nCi} / \mathrm{g}{ }^{244} \mathrm{Cm}$ in the Zircaloy after 5 years cooling. The balance of the transuranics would be less than $3 \mathrm{nCi} / \mathrm{g}$ total. (1) Higher levels of TRU elements would be present if irradiated longer. A similar calculation of the transuranics generated in the Inconel and stainless steel parts could be made; however, a satisfactory estimate of the uranium and thorium impurities in these alloys has not yet been obtained. The $\mathrm{Zr}$ cladding has been estimated to contain 100 to $150 \mathrm{ppm}$ hydrogen of which about $0.03 \mathrm{wt} \%$ is fission product tritium. $(2,3)$

LWR fuel elements might have a corrosion product layer up to $50 \mu$ thick in locations of maximum corrosion. (4) Impurities (crud) circulating in the reactor deposit on fuel surfaces and can contain transuranics if the coolant is contaminated with uranium or plutonium from fuel ruptures. The internal surface of the Zircaloy-clad fuel develops an oxide layer of a few microns in thickness. ${ }^{(4)}$ The ( $\left.U, P u\right) 0_{2}$ fuel has been observed to adhere and possibly react with this oxide layer. ${ }^{(5 T}$ Estimates of residual $(\mathrm{U}, \mathrm{Pu}) \mathrm{O}_{2}$ associated with the fuel cladding after leaching are usually stated as less than 0.1 wt\% of the uranium charged. $(6,7,8)$ Analysis of two irradiated leached fuel cladding pieces has shown considerably less than 0.1 wt\% residual fuel, but with much higher than expected ${ }^{137} \mathrm{Cs} .(9,10)$

\section{CONCLUSIONS}

The Inductoslag process can produce, with prior decontamination and sorting, Zircaloy, stainless steel, and Inconel ingots of a quality suitable for refabrication and reuse. Prior surface preparation is not necessary to produce ingots of these materials and their mixtures for direct storage. $\mathrm{Zr}$-containing ingots can also be used as tritium reservoirs. The melting system is nearly free of refractories and crucible life is exceptionally long. Although the $\mathrm{CaF}_{2}$ or $\mathrm{CaF}_{2}-\mathrm{MgF}_{2}$ slag will result in a waste stream, it can be recycled. 
The graphite crucible eutectic process can melt alloys of Zircaloy, stainless steel, and Inconel in the range of 80 to $85 \mathrm{wt} \%$ Zircaloy at temperatures of $1300^{\circ} \mathrm{C}$. Decontamination prior to melting could result in a low volume, low radioactive waste form for direct storage. These alloys could also be used as storage reservoirs for tritium. The percentage of Zircaloy in the chop-leach hulls is conveniently near the desired eutectic composition, thus eliminating the need to melt at the high melting point of $\mathrm{Zr}, \sim 1850^{\circ} \mathrm{C}$. Spent crucibles could be burned to an ash to reduce the waste stream. Crucible life will probably be less than that of cold crucibles and refabrication of the ingot would not be possible. 


\section{MELT DENSIFICATION PROCESSES}

Two melting processes have been investigated for the densification of fuel bundle residues: 1) Inductoslag melting and 2) graphite crucible melting. Decontamination of the melt stock prior to melting can enhance melting characteristics and result in ingots with storage and transportation requirements that are less costly. Sorting by alloy grade could result in metal suitable for reuse in a nuclear facility when melted by the Inductoslag process.

Although detailed descriptions of decontamination processes are outside the scope of this report, the development of decontamination processes is a parallel effort of this program. Because decontamination methods for nickel and iron base alloys have been established, initial efforts have been directed to the more difficult task of decontaminating Zircaloy surfaces with minimum loss of metal. The most promising process investigated to date has been treatment of the $\mathrm{ZrO}_{2}$ corrosion films in Hf-Argon gas at 550 to $650^{\circ} \mathrm{C}$ which produces films that are removable in a dilute aqueous reagent developed by Meservey. (11) The Hf-Argon gas-treated residues are heated at $90^{\circ} \mathrm{C}$ for 1 to $2 \mathrm{hr}$ in this solution which consists of $0.4 \mathrm{M}$ ammonium oxalate, 0.16M ammonium citrate, 0.1M ammonium fluoride and $0.3 \mathrm{M}$ hydrogen peroxide. Technology such as distillation, pyrohydrolysis and calcination exists for treating or recycling of waste side streams. TRU element decontamination factors of about $10^{4}$ will be necessary to reduce transuranics to $<10 \mathrm{nCi} / \mathrm{g}$.

\section{INDUCTOSLAG MELTING}

The chemical activity of $\mathrm{Zr}$ at its melting point $\left(21850^{\circ} \mathrm{C}\right)$ requires that it be melted in vacuum or inert atmosphere. Conventional crucible materials react vigorously with molten $\mathrm{Zr}$. For example, $\mathrm{Zr}$ melted in graphite crucibles picks up excessive carbon. Consequently, cold crucible processes were developed for producing $\mathrm{Zr} .{ }^{(12)}$ These processes have also been used for remelting iron, nickel, and cobalt alloys. Alternate cold crucible melting techniques have been evaluated in the context of fuel bundle 
residue densification. (13) Conclusions from this evaluation resulted in selecting the Inductoslag process as the most promising process for this application.

The Inductoslag melting process (Figure 1), developed by Clites and Beal1 14,15$)$ of the U.S. Bureau of Mines in Albany, Oregon, uses inductionheating. The melt is insulated from a split, water-cooled crucible by a layer of frozen slag. Melting takes place in static, one-third atmospheric pressure helium. A pool of Zircaloy-4 and $\mathrm{CaF}_{2}$ is melted on a "starting stub" and subsequent charge material vibratorily fed into the top of the crucible as the ingot is extracted out the bottom of the crucible.

Zircaloy-4 fuel cladding chopped into $2.5-\mathrm{cm}$ pieces and etched by the ammonium oxalate, citrate, fluoride, peroxide bath similar to that used in the decontamination process was used as feed material to the Inductoslag process to produce an ingot $10-\mathrm{cm}$ diameter $\times 75-\mathrm{cm}$ long and weighing $41 \mathrm{~kg}$. (16) The scalloped appearance of the ingot sidewall shown in Figure 2 is a result of the split copper crucible design. The fine grained area at the top of the longitudinal cross section is the last metal to freeze and represents the extent of the molten pool during the melting process. Power input during melting was $95 \mathrm{~kW}$, resulting in a melting rate of $19 \mathrm{~kg} / \mathrm{hr}$.

Chemical analyses and hardness testing of the ingot showed it to be within nuclear grade specification. Carbon and hydrogen did not increase. Nitrogen increased $\sim 30 \mathrm{ppm}$ and oxygen $\sim 300 \mathrm{ppm}$. Fluorine increased $\sim 16 \mathrm{ppm}$; no calcium increase was detected. The average hardness was 180 Brinell.

Portions of the ingot were extruded and refabricated by a commercial cladding tube manufacturer into a cladding tube size of $11.2 \mathrm{~mm}$ OD $\times 0.74 \mathrm{~mm}$ wal1. Standard autoclave testing of the refabricated cladding tube showed normal weight gain and black lustrous surfaces. $(9,16)$

Clean 304 SS, Inconel 718, and a 2:1 by weight mixture of 304 SS and Inconel have been melted by the Inductoslag process. Successive $10-\mathrm{kg}$ melts were made one on top of the other to form a three-component ingot. Because of the lower melting range of these materials, a eutectic mixture of $48 w t \% \mathrm{CaF}_{2}-52 \mathrm{wt} \% \mathrm{MgF}_{2}$ is used as the slag. The eutectic melts at 


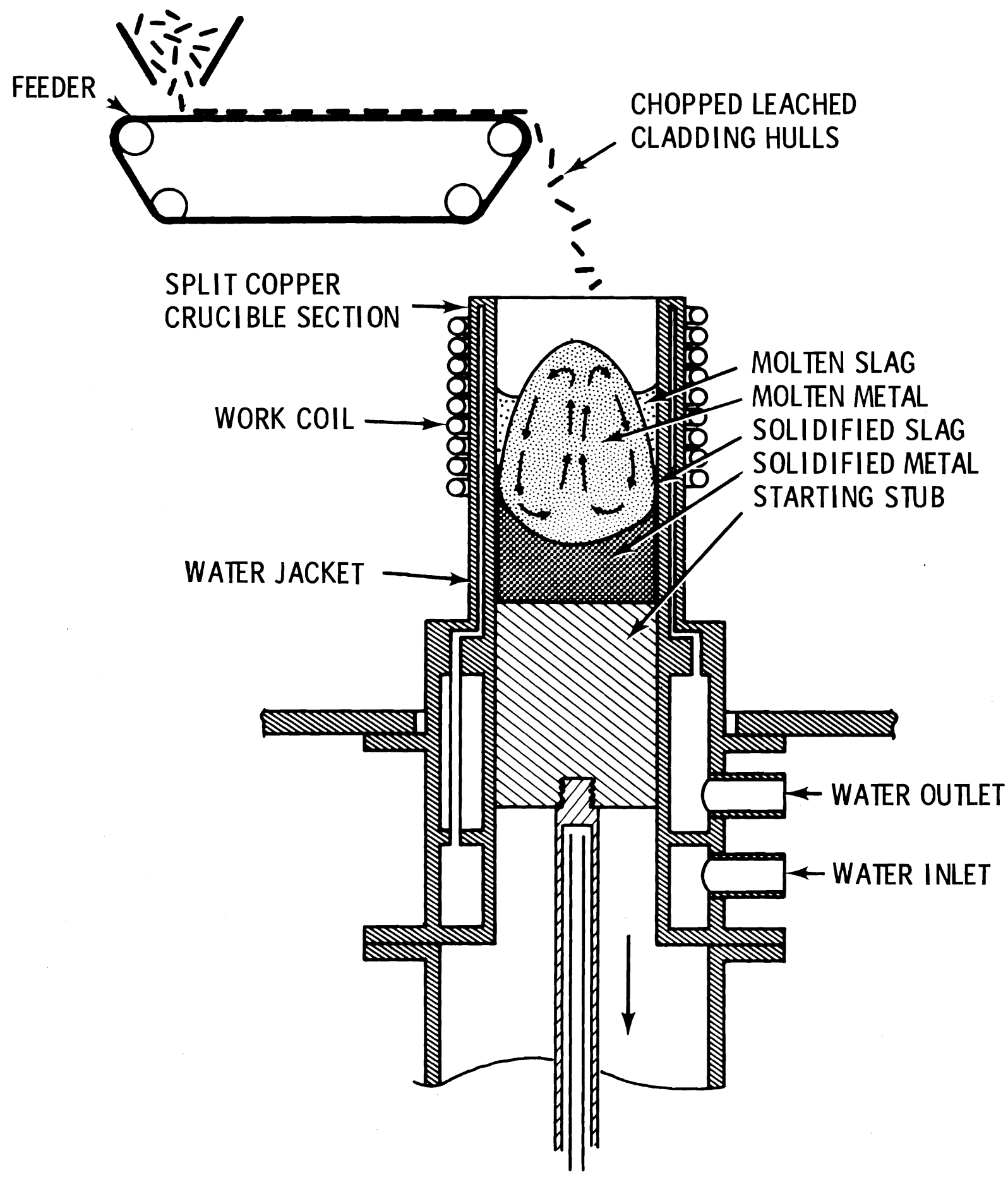

FIGURE 1. Inductoslag Melting Process. Clites and Beall, Albany Metallurgical Research Center, U.S. Bureau of Mines, Albany, Oregon. (15) 


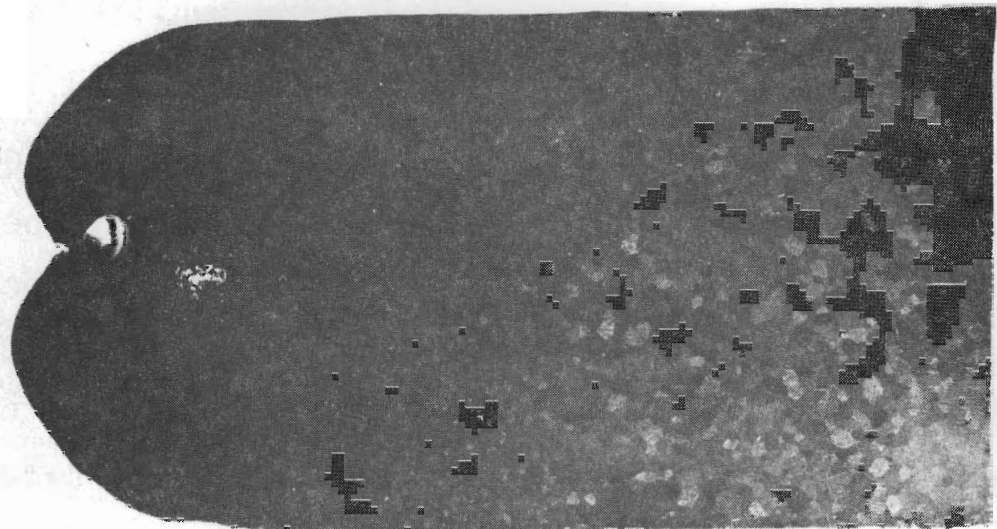

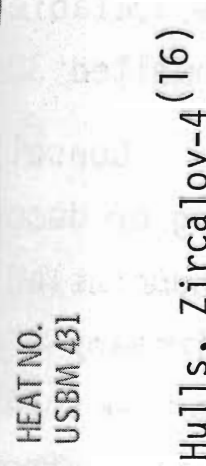

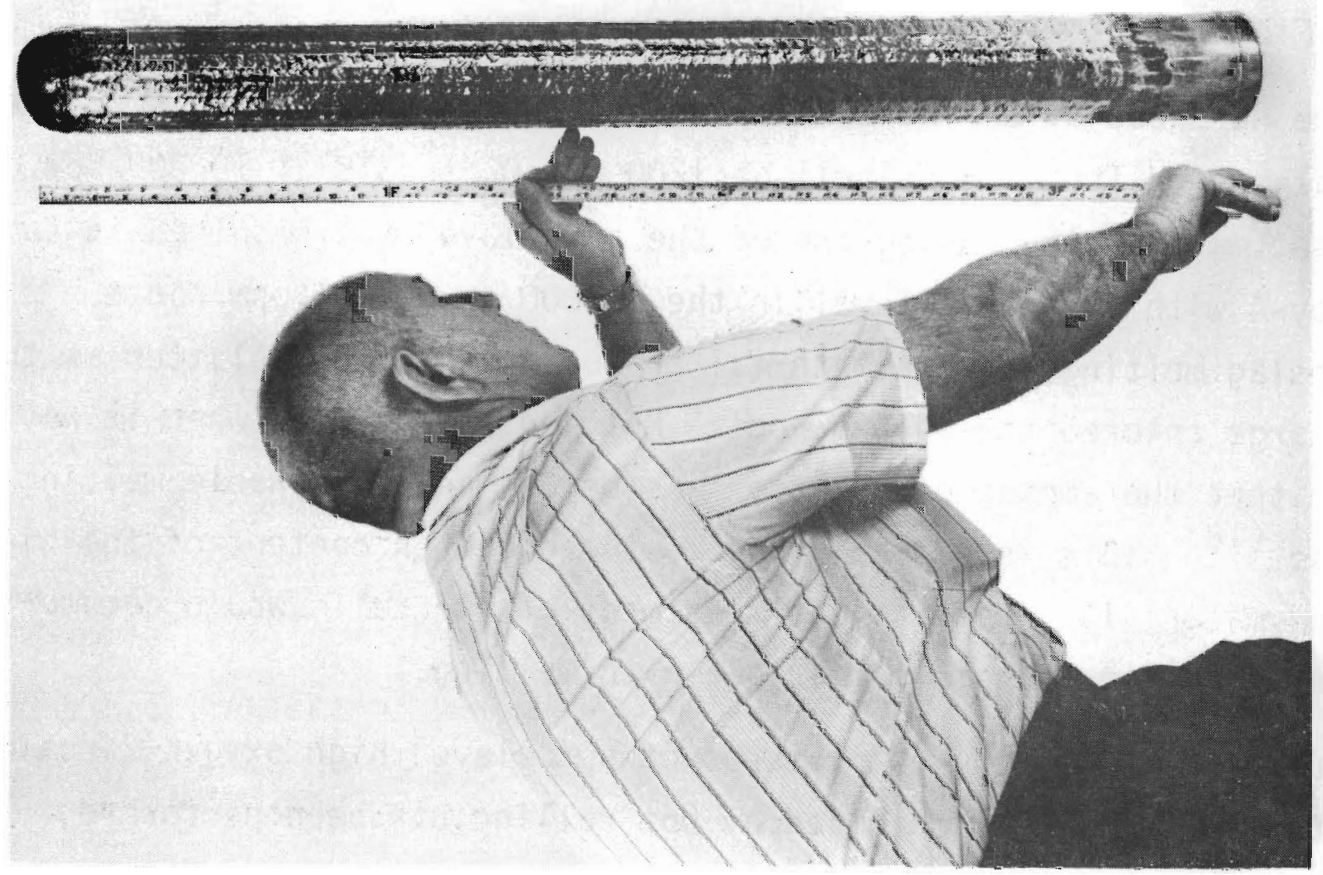

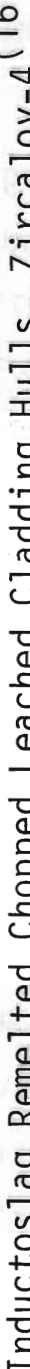

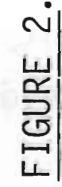


$1000^{\circ} \mathrm{C}$, while the $\mathrm{CaF}_{2}$ alone melts at $1360^{\circ} \mathrm{C}$. Eighty-five to $95 \mathrm{~kW}$ produced a melting rate of $28 \mathrm{~kg} / \mathrm{hr}$ for the $304 \mathrm{SS}$ and $15 \mathrm{~kg} / \mathrm{hr}$ for the $2: 1$ mixture and the pure Inconel 718. ${ }^{(9)}$ Figure 3 shows transverse etched ingot sections of these materials. The $304 \mathrm{SS}$ and Inconel ingots are of a quality that is suitable for direct storage or refabrication, while the mixture with unmelted 304 SS is suitable for direct storage only.

Consolidation by melting of fuel bundle residues without prior cleaning or decontamination may be desirable for materials to be stored only. Inductoslag melting of oxidized fuel bundle residues has been accomplished. Zircaloy-4 cladding has been oxidized by autoclave at 500 to $525^{\circ} \mathrm{C}, 200$ psi for 40 to $48 \mathrm{hr}$. This resulted in a total oxygen content of the Zircaloy ranging from 1200 to $10,000 \mathrm{ppm}$, an oxygen content estimated to be present in full-term irradiated hulls. The melting characteristics of this material appeared to be nearly identical to those of clean hulls. The high $(10,000 \mathrm{ppm})$ oxygen material produced some splattering and smoke during melting, but melting was not inhibited. Melting at $85 \mathrm{~kW}$ resulted in a melting rate of $20 \mathrm{~kg} / \mathrm{hr} .{ }^{(17)}$ The external appearance and the etched sections shown in Figure 4 are nearly identical to those of the low oxygen ingot (Figure 2).

The hardness of $\mathrm{Zr}$ increases with increased oxygen content. This material ranged from 175 Brinell at $1200 \mathrm{ppm} 0_{2}$ to 375 at $10,000 \mathrm{ppm}$. Equipment malfunction during one of the autoclave runs resulted in some Zircaloy-4 with an oxygen level in the 20,000 to 40,000 ppm range. Inductoslag melting of this material produced excessive splatter as the cold charge entered the molten pool. Melting was stopped when it was evident that the amount of splatter was beyond any reasonable melting practice. (18) This is probably due to the hydrogen content of the highly oxidized material. Premelt heat treatment of the hulls would reduce the hydrogen level to a range compatible with melting.

Inductoslag melting of mixtures of autoclaved high oxygen Zircalogy with 304 SS and Inconel oxidized by hot rolling has been performed. These compositions consisted of: 


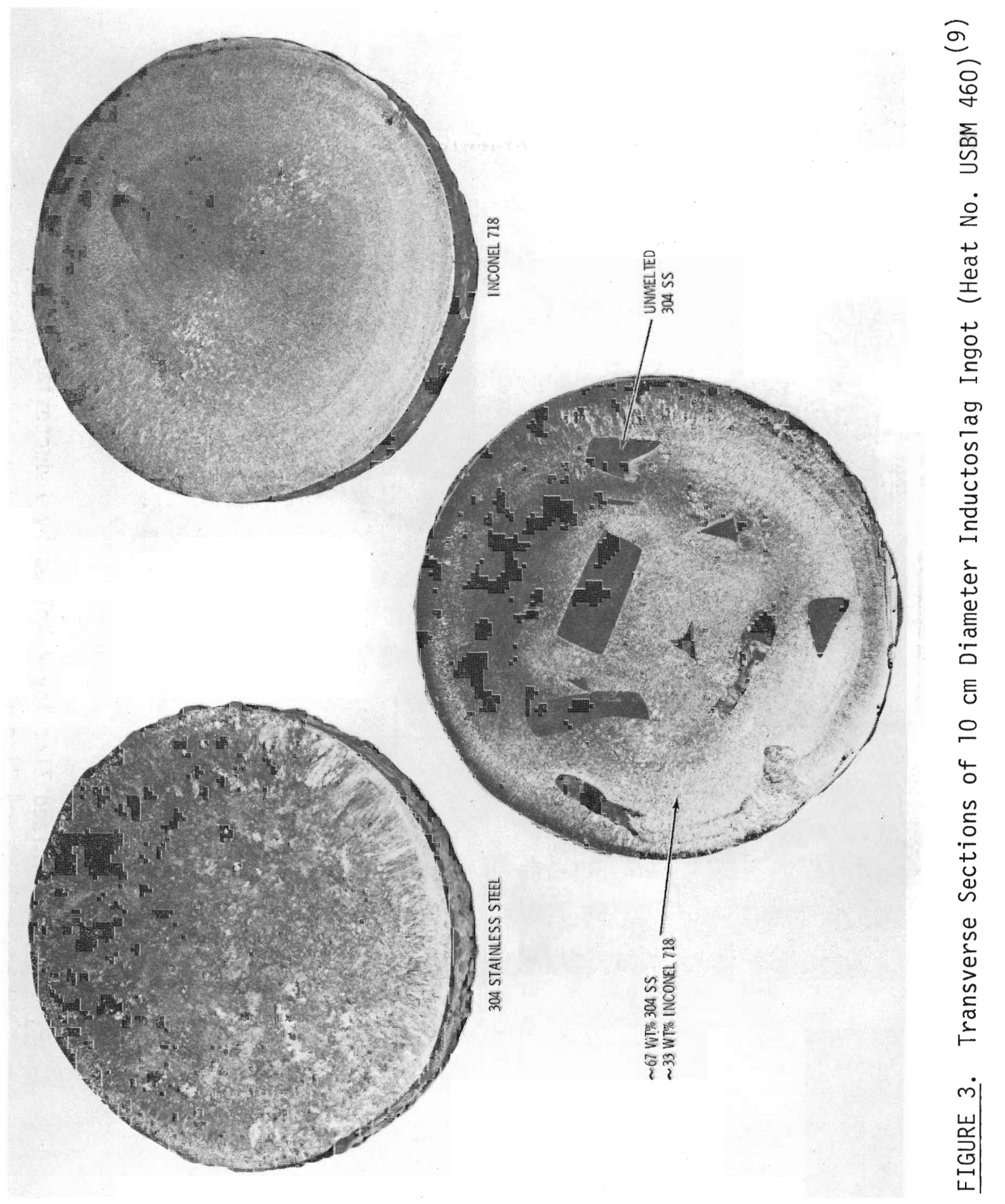




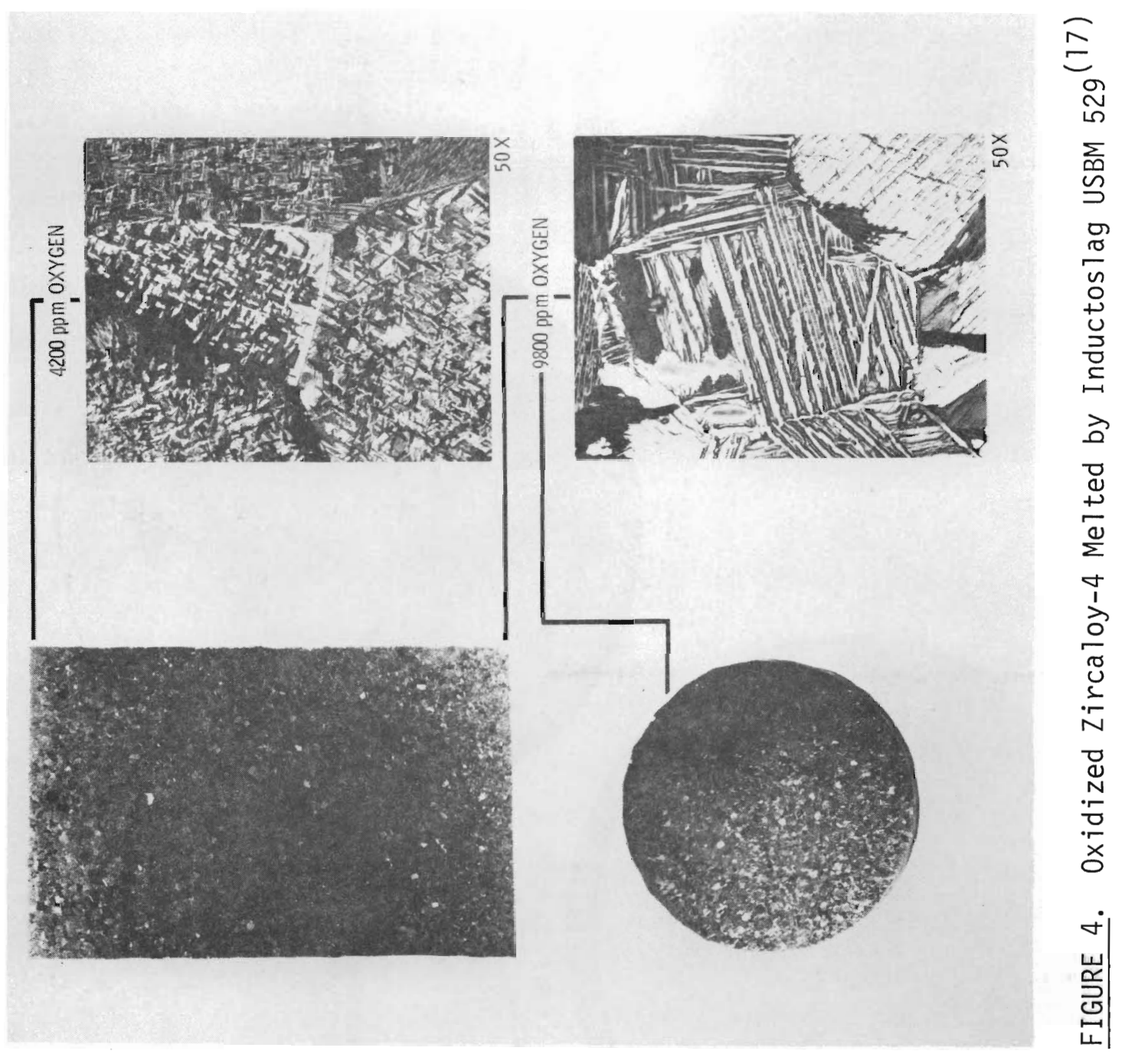


1. Zircaloy-4 with 3000 to $8000 \mathrm{ppm} \mathrm{O}_{2}$ with 4 wt\% oxidized Inconel 718

2. Zircaloy-4 with 3000 to $8000 \mathrm{ppm} \mathrm{O}_{2}$ with $10 \mathrm{wt} \%$ oxidized Inconel 718

3. Zircaloy-4 with 3000 to $8000 \mathrm{ppm} 0_{2}$ with 10 wt\% oxidized 304 SS and 5 wt\% oxidized Inconel 718.

These mixtures represent a range of partially segregated fuel bundel residues and were melted using $48 \mathrm{wt} \% \mathrm{CaF}_{2}-52 \mathrm{wt} \% \mathrm{MgF}_{2}$ slag. The mixtures form the low melting eutectic and result in unmelted metal potted in the eutectic matrix. Figures 5 and 6 are typical of these alloys. The ingots are free of voids and suitable for direct storage; however, they are subject to cracking induced by severe thermal gradients. (17)

The low temperature molten pool is slow in dissolving the feed material, causing excessively slow melting rates. A power input of $85 \mathrm{~kW}$ results in melting rates of 5 to $8 \mathrm{~kg} / \mathrm{hr}$. Efforts are currently under way to increase the melt rate of these alloys.

Aluminum oxide pellets have been added to these materials durino melting to simulate the insulator pellets in the fuel bundle residues. They do not interfere with melting and occur as "potted" unreacted inclusions in the ingot.

\section{GRAPHITE CRUCIBLE MELTING}

Graphite crucible melting, although not as versatile as Inductoslag melting, gave good results. While $\mathrm{Zr}$ melts at $\sim 1850^{\circ} \mathrm{C}$, binary mixtures of $\mathrm{Zr}$ with iron, nickel and chromium form low melting eutectics that can lead to simplified melting processes. ${ }^{(19)}$ Figure 7 shows the binary equilibrium diagrams of $\mathrm{Zr}$ with iron, nickel, and chromium. Fortunately the low melting eutectics occur at the approximate composition of the fuel bundle residues. Decontamination of the residues prior to melting will provide clean metallic surfaces for diffusion, resulting in liquid formation.

Melting point determinations were made on pre-alloyed $150 \mathrm{~g}$ ingots of Zircaloy-2 with 10,15 and 20 wt\% 316 SS. These were performed under vacuum in graphite crucibles heated by a tungsten resistance element. A11 three 


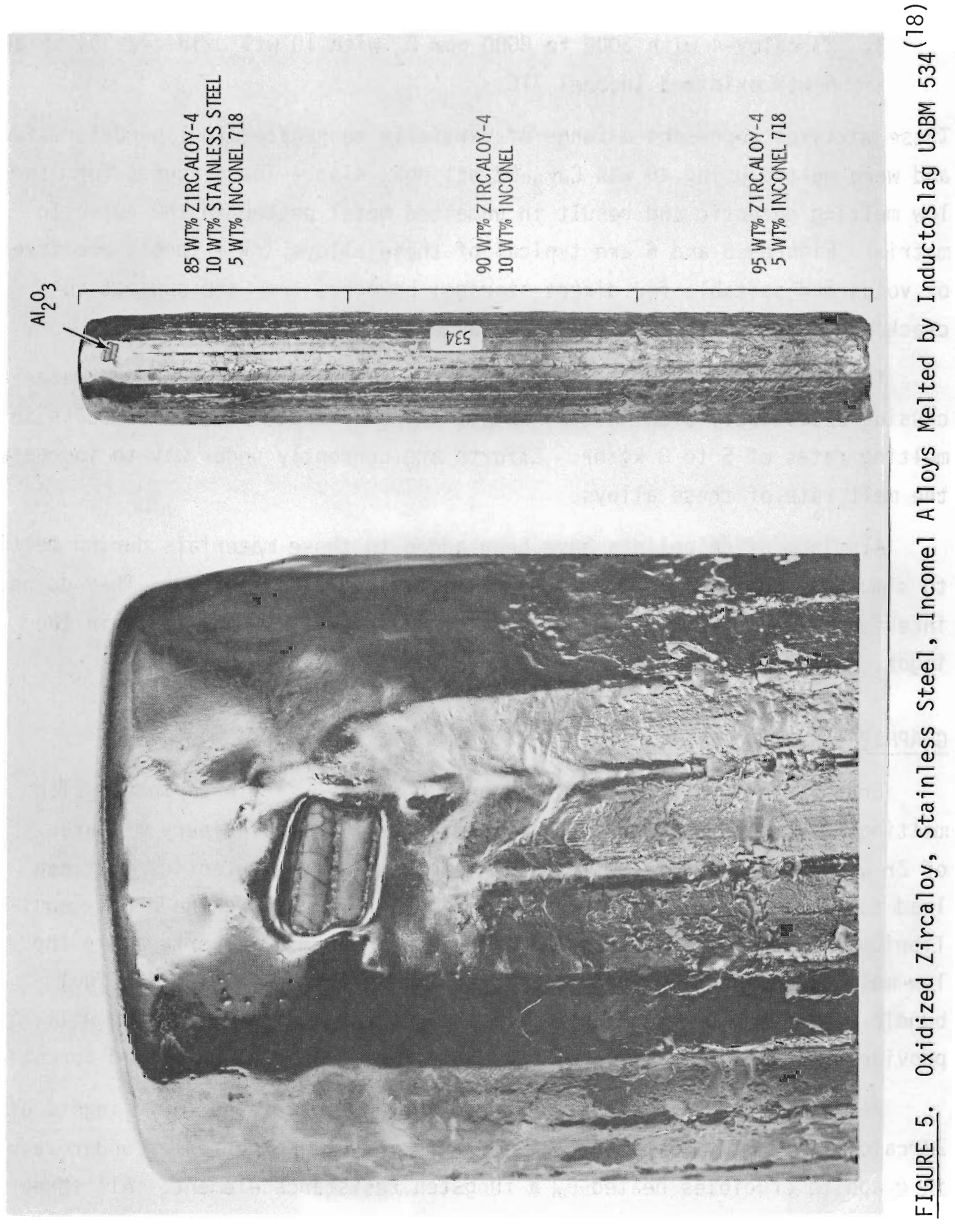




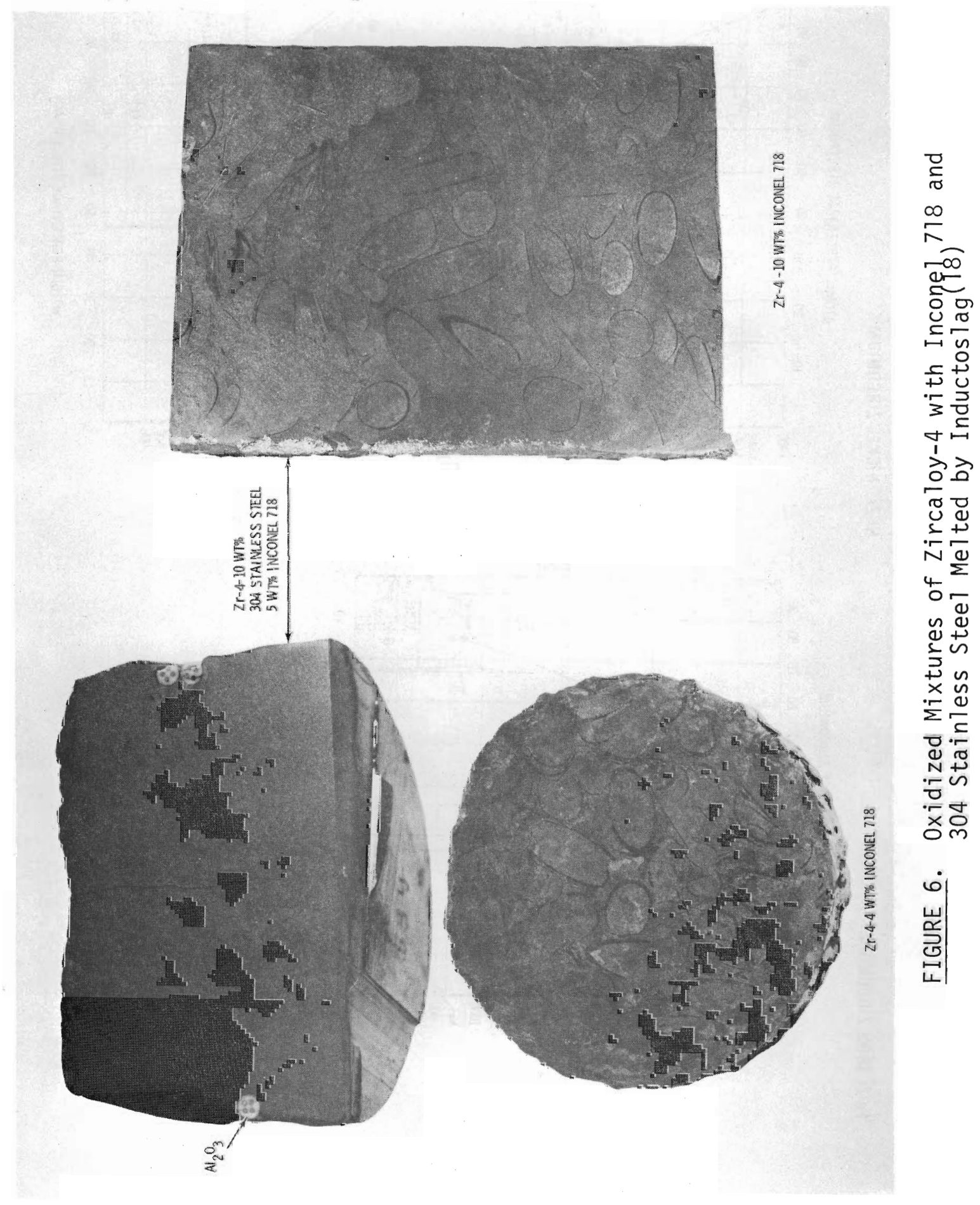



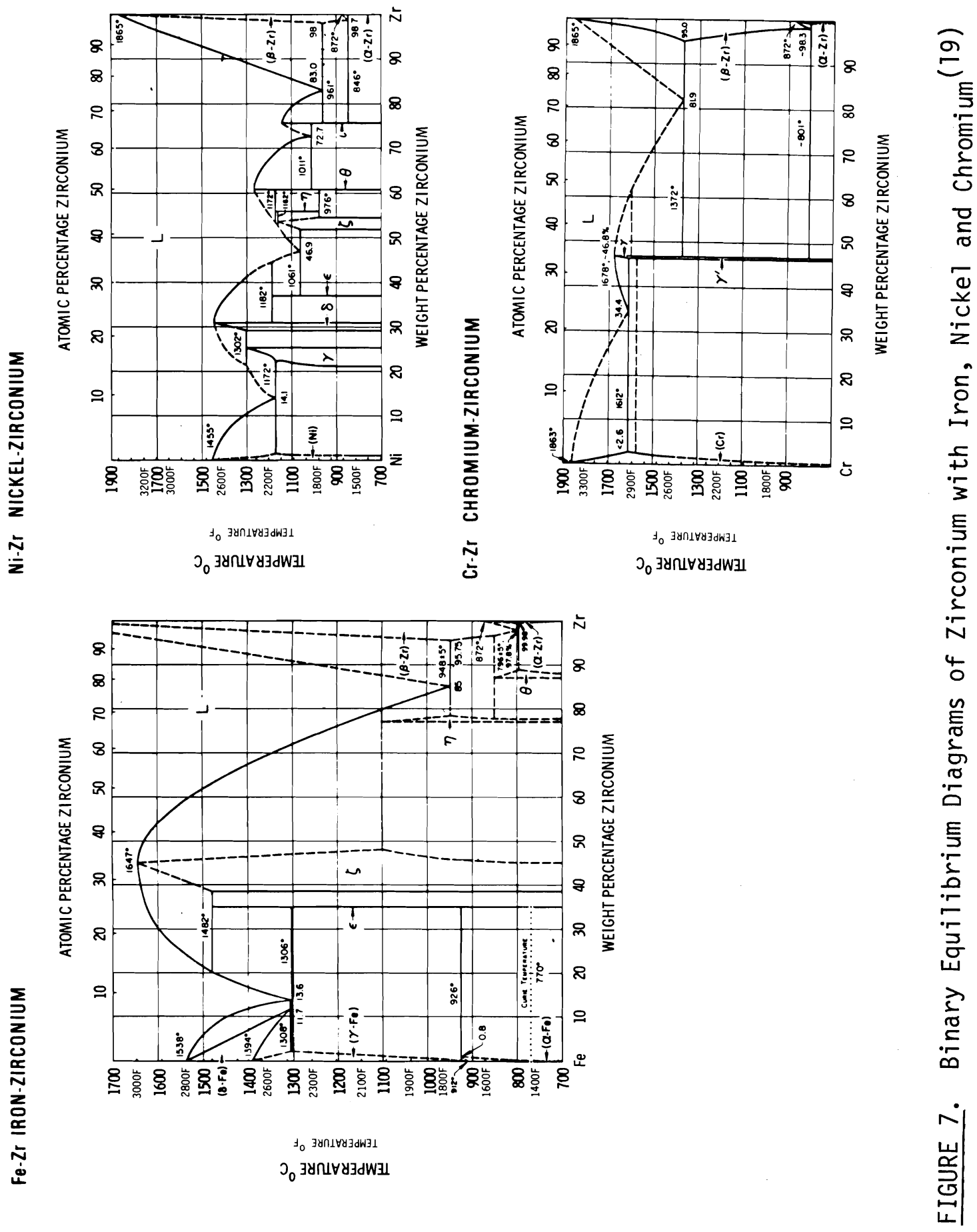
compositions start melting at about $925^{\circ} \mathrm{C}$. The 15 and $20 \%$ alloys complete melting at about $1100^{\circ} \mathrm{C}$, whereas melting is incomplete for the Zircaloy-2, $10 w t \%$ ss alloy. (20)

Scale-up of this work to $8.2 \mathrm{~kg}$ heats was performed with a $50 \mathrm{~kW}$, 3000 cycle vacuum induction melting furnace. The crucible and coil assembly are of the tilt type. A graphite susceptor heats an outer graphite crucible which in turn neats the inner or melting crucible. Melting stock was clean sheet chopped into $2.5-\mathrm{cm}$ squares. The 14.0-cm diameter crucible was charged with layers of the 304L SS-Inconel mixture between layers of Zircaloy-2. The heats were started at $5 \times 10^{-4}$ Torr chamber pressure with a power setting of $5 \mathrm{~kW}$ and gradually increased to $10 \mathrm{~kW}$. The pouring temperature was reached in approximately 2.5 to $3 \mathrm{hr}$, held for $30 \mathrm{~min}$, and poured into an $8.9-\mathrm{cm}$ diameter $\times 30.5 \mathrm{~cm}$ deep split graphite mold. Five 8.2-kg heats made to date have been poured into the same mold and no mold reaction has been observed. $(10,21)$

Figure 8 shows the 85 wt\% Zircaloy-2, 10 wt\% 304L SS, 5 wt\% Incone1 718 ingot that was poured at about $1300^{\circ} \mathrm{C}$. A slightly higher pouring temperature or a preheated mold would reduce the skirt at the top of the ingot. A very mild crucible reaction was noted.

A mild crucible reaction was also noted in the $80 \mathrm{wt} \%$ Zircaloy-2, $13.4 \mathrm{wt} \% 304 \mathrm{~L} \mathrm{SS}, 6.6 \mathrm{wt} \%$ Inconel 718 ingot poured from $1315^{\circ} \mathrm{C}$ (Figure 9). The ingot had surface cracks. The cracks were eliminated when the melt was allowed to cool in the crucible (Figure 10); however, excessive crucible reaction bonded the ingot to the crucible.

Figure 11 shows the 90 wt\% Zircaloy-2, 6.7 wt\% 304L SS, 3.3 wt\% Incone1 718 ingot poured from $\sim 1415^{\circ} \mathrm{C}$. Higher pouring temperatures would be required to successfully pour this composition. A severe crucible reaction was observed.

An example of a typical microstructure is given in Figure 12 of the as-polished 85 wt\% Zircaloy-2, 10 wt\% 304L SS, 5 wt\% Inconel 718 alloy showing three major microconstituents and their approximate compositions as determined by microprobe analyses. 


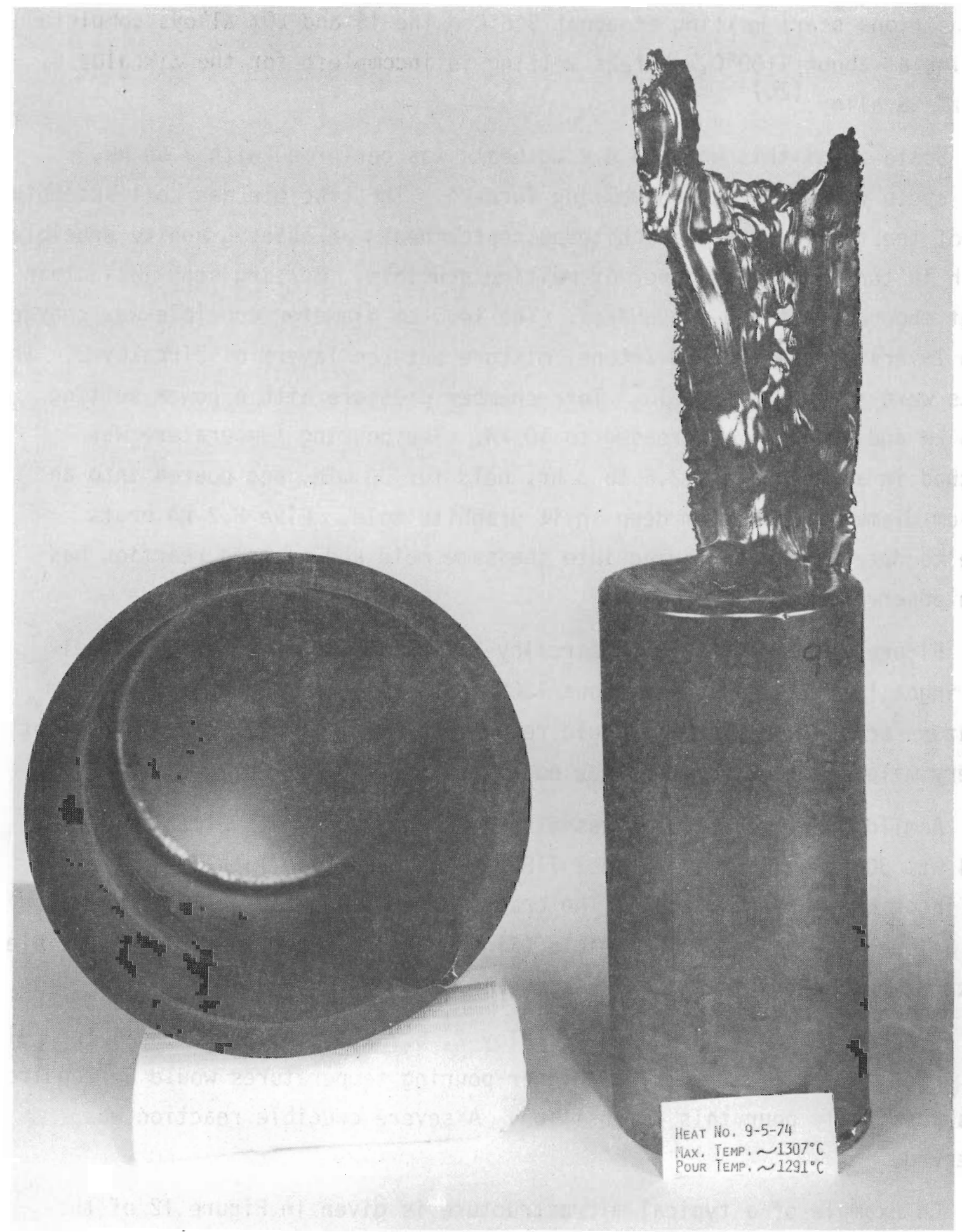

FIGURE 8. $85 w t \%$ Zircaloy-2, 19 wt\% 304L Stainless Steel, 


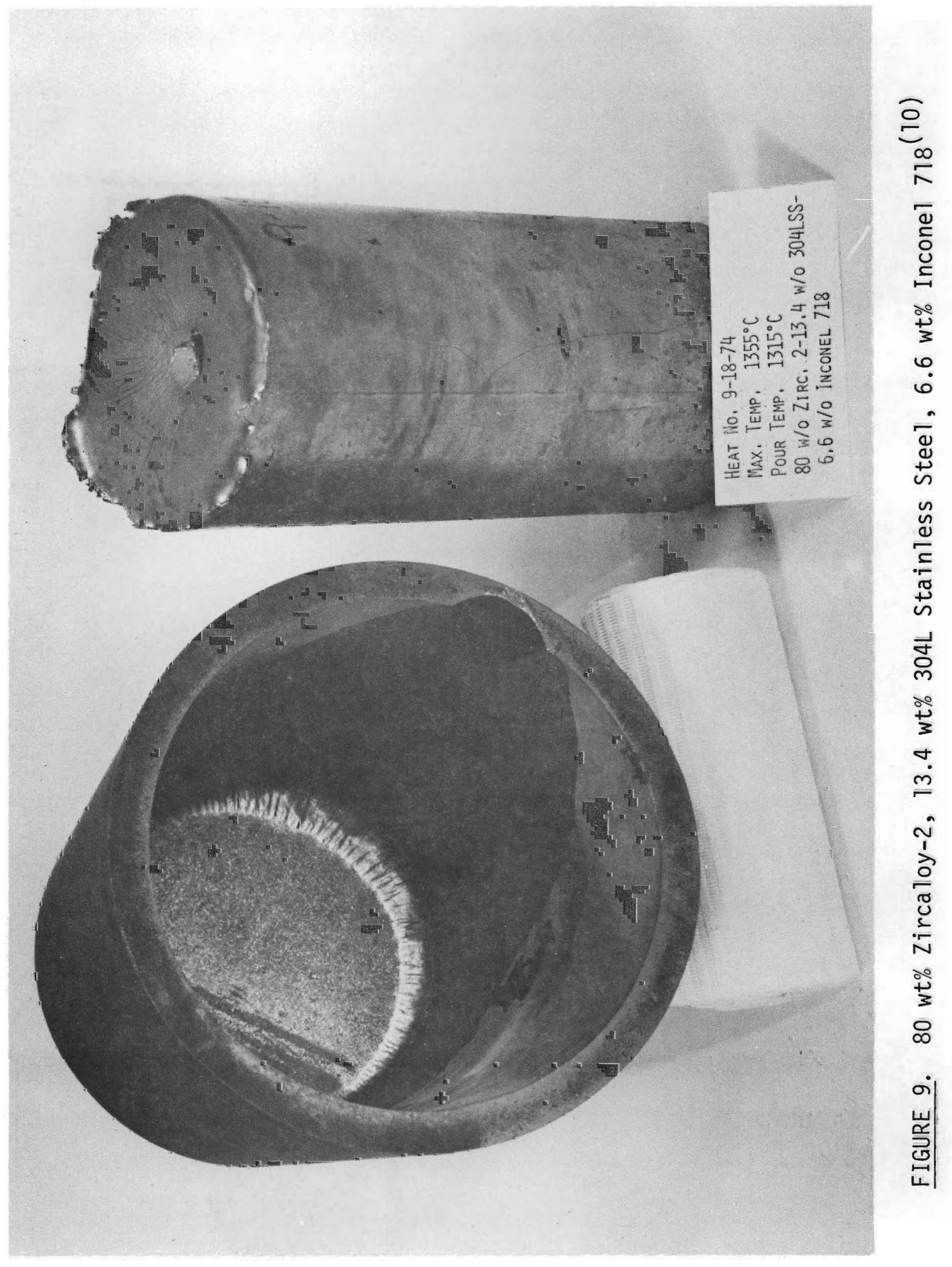




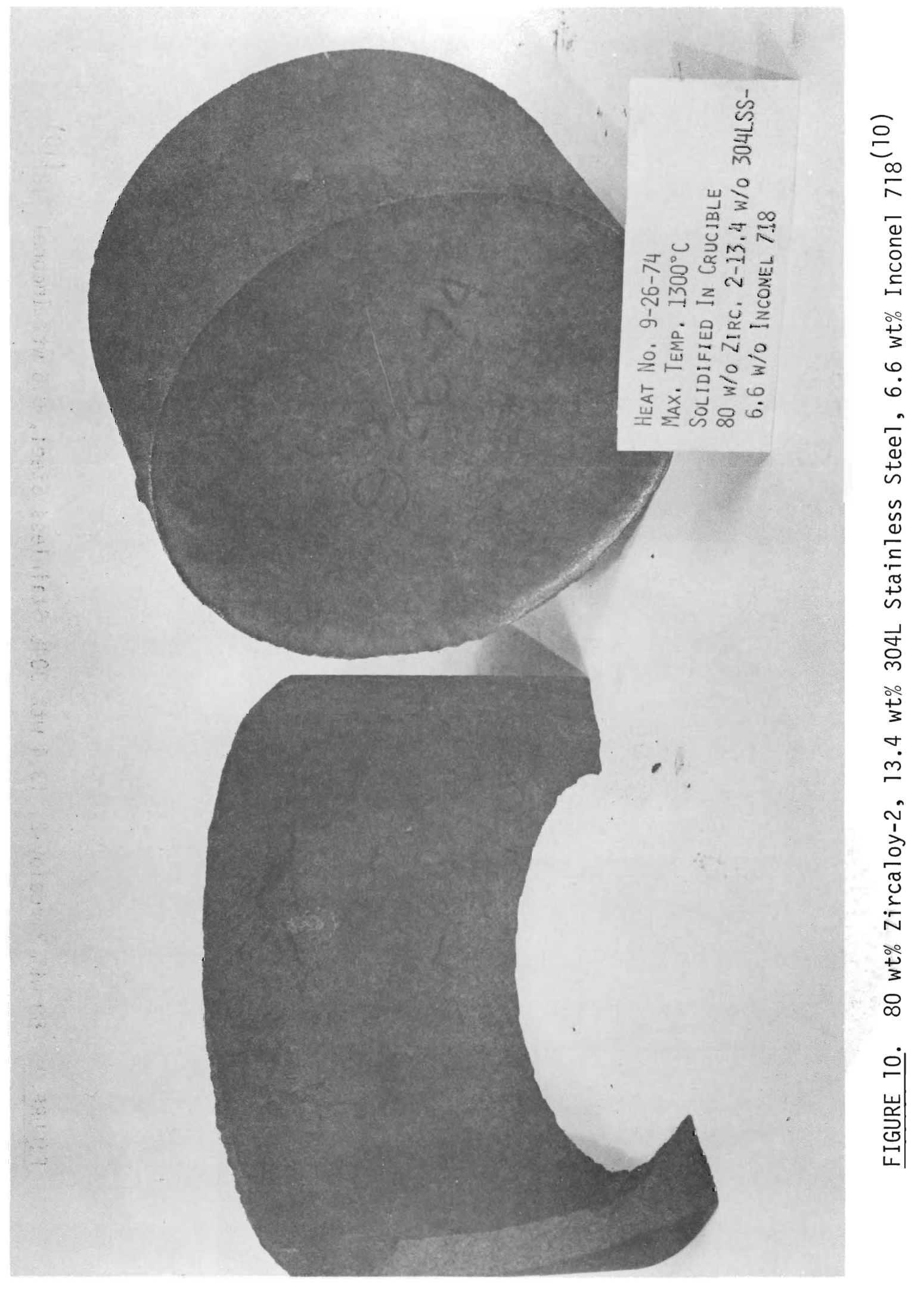




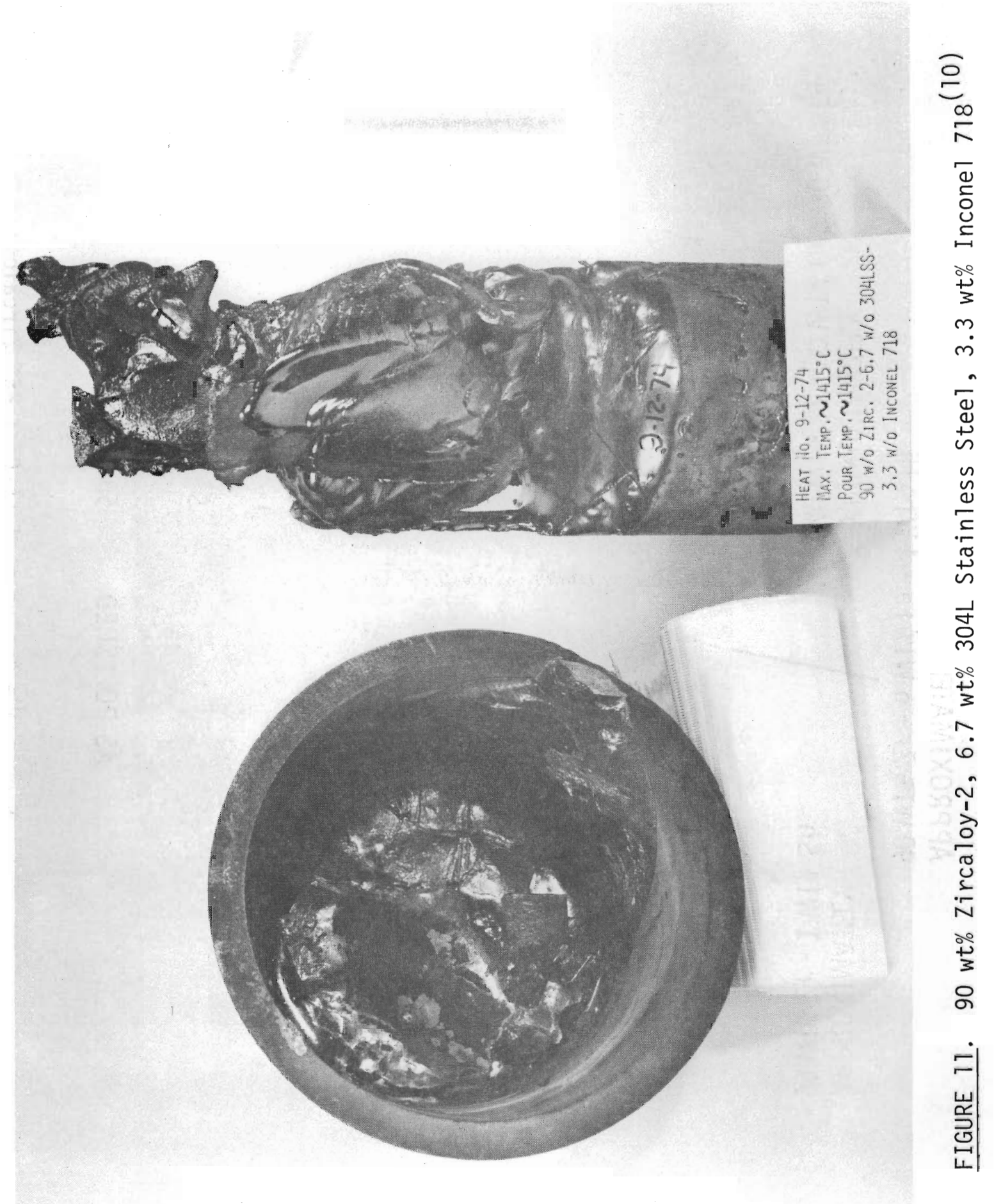




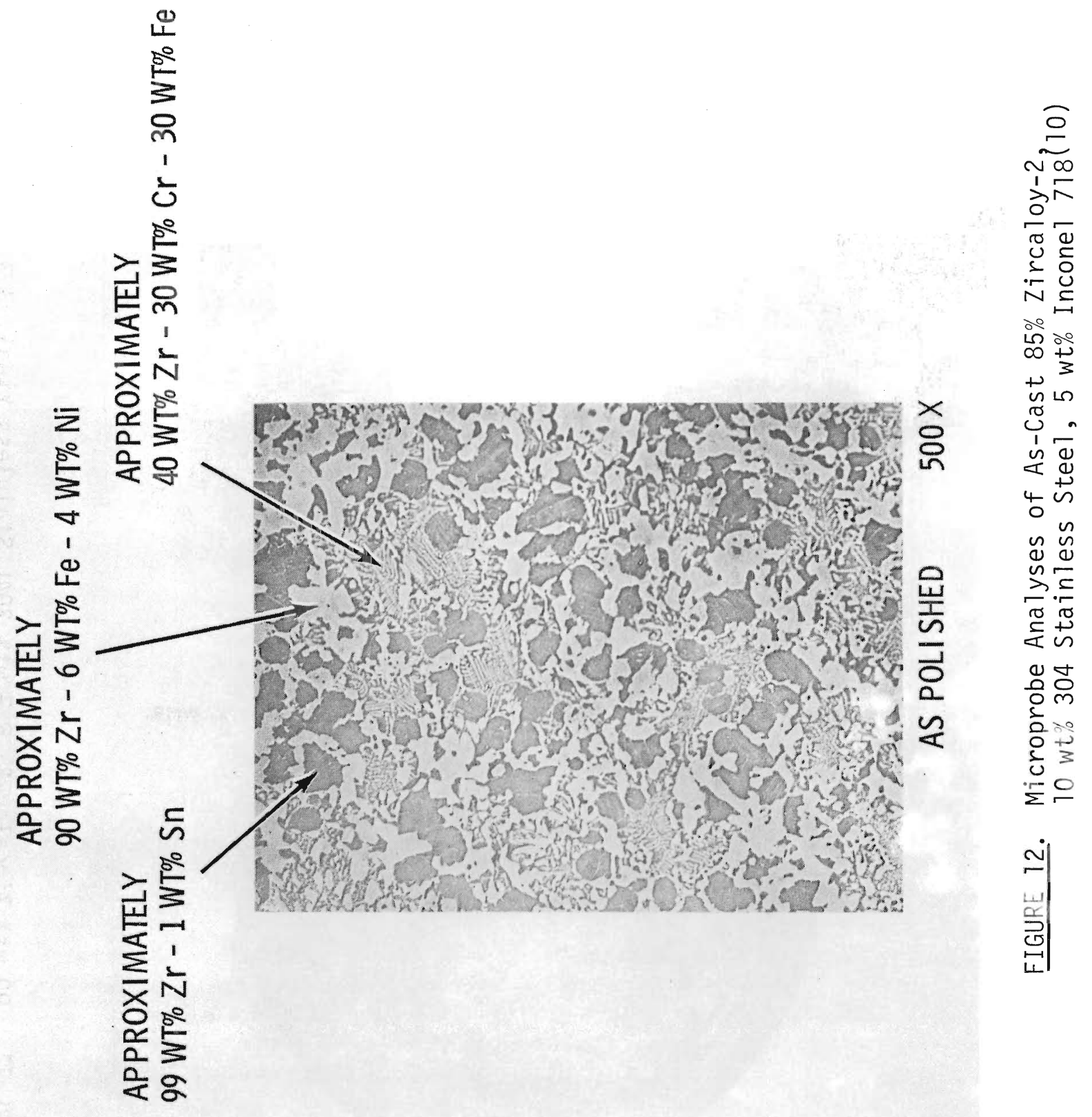


Concentrations of major metallic elements of these heats agreed reasonably well with the design compositions. Carbon, hydrogen, oxygen and nitrogen values for the melting stock and the resulting heats are listed in Table 1.

TABLE 1. Chemical Analyses of Interstitials (10)

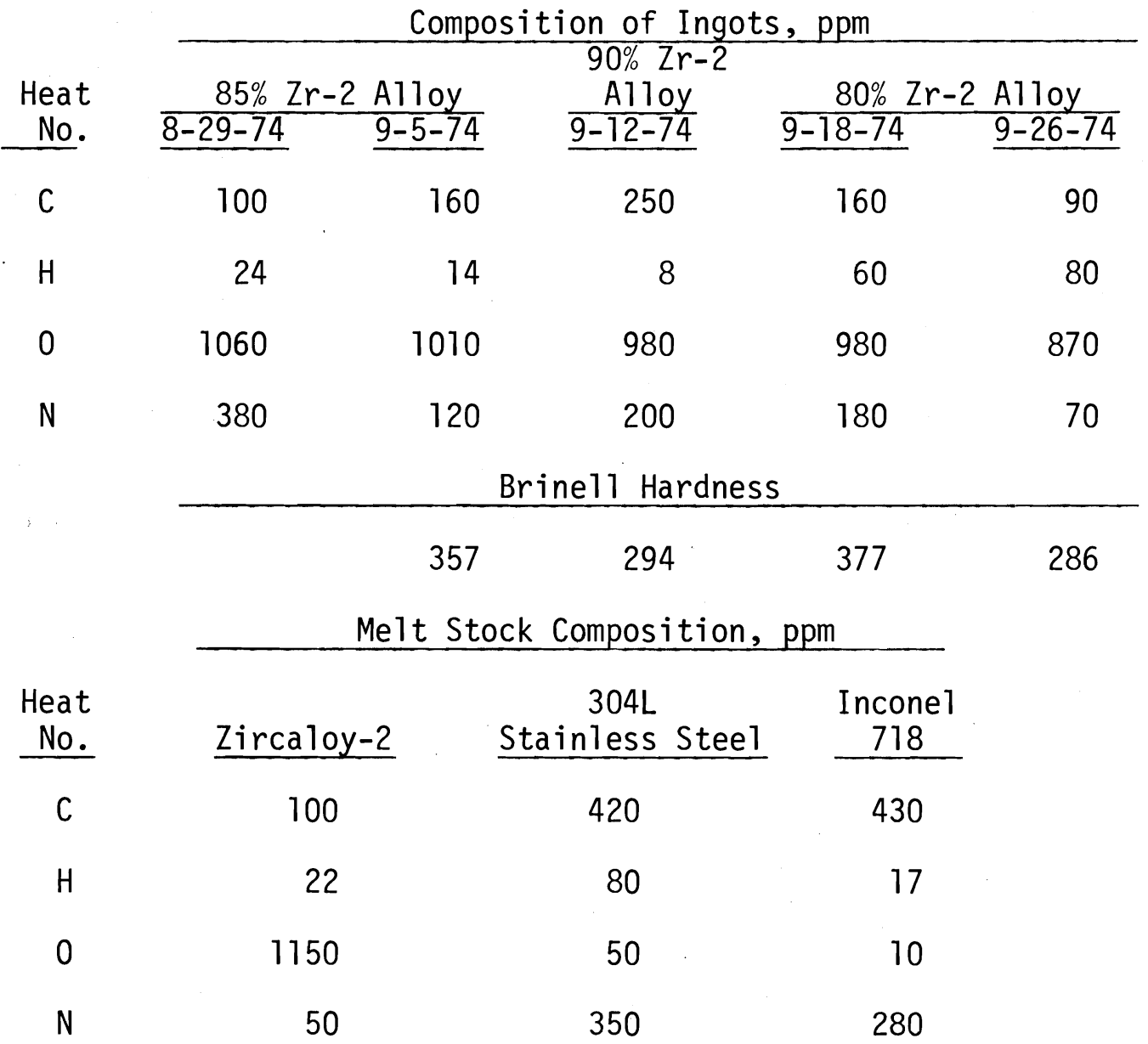

Carbon pickup from melting in the graphite crucible is minimal. The $250 \mathrm{ppm}$ carbon level was the result of a high pouring temperature $\left(1415^{\circ} \mathrm{C}\right)$. The melting of pure $\mathrm{Zr}$ in graphite at temperatures of 1820 to $1920^{\circ} \mathrm{C}$ will result in carbon contents as high as $3000 \mathrm{ppm}$. ${ }^{(5)}$ Hydrogen and oxygen showed little or no increase after melting and nitrogen was slightly raised. 
Brinell hardness values of the as-cast ingots range from 294 to 377 . Ingots have been successfully hack sawed with high speed tool steel blades and water soluble oil coolant.

The melting experiments described above show that mixtures of clean sheet composed of 80 to 85 wt\% Zircaloy balance stainless stee 1 and Inconel can be melted and poured at temperatures about $1300^{\circ} \mathrm{C}$ using graphite crucibles and molds. Although slight crucible reactions do occur, the crucibles are reusable. Ingot surface quality and density appear adequate for direct storage. Controlled mold cooling may be required to eliminate surface cracking of the 80 wt\% Zircaloy composition.

\section{TRITIUM ABSORPTION AND STORAGE IN ZIRCONIUM ALLOY INGOTS}

The melting of fuel hardware into ingots will release absorbed hydrogen and tritium. Consequently 100 to $150 \mathrm{ppm}$ of hydrogen and tritium evolved can be reabsorbed into another ingot. The absorption rate and equilibrium pressure of hydrogen over Zircaloy and $\mathrm{Zr}-(\mathrm{Fe}, \mathrm{Ni}, \mathrm{Cr}$ ) alloy ingots melted in graphite were investigated at representative gas pressure and concentration (Figure 13). The absorption temperature was fixed high enough $\left(700^{\circ} \mathrm{C}\right)$ that Zr would dissolve its own oxides and nitrides which would otherwise impede absorption. (16) A large temperature gradient was imposed over the length of the absorption specimen to increase the capacity of the ingot for hydrogen while keeping equilibrium gas pressure down. Absorption rates for Zircaloy-2 and 85\% Zircaloy-2, 10\% Type 304 SS, 5\% Inconel 718 specimens with grit blasted surfaces were compared. In general, the equilibrium pressures were controlled by the $\mathrm{Zr}$ concentration. The rate of absorption favored the Zircaloy-2. The re-hydriding of the $\mathrm{Zr}$ alloy always resulted in faster subsequent absorption rates even though the hydrogen was removed before the second absorption. This suggests the development of a preferred path for absorption and diffusion. Both the alloy and Zircaloy-2 absorb hydrogen rapidly enough to be useful for storage of the hydrogen and tritium removed from the densified hulls. 


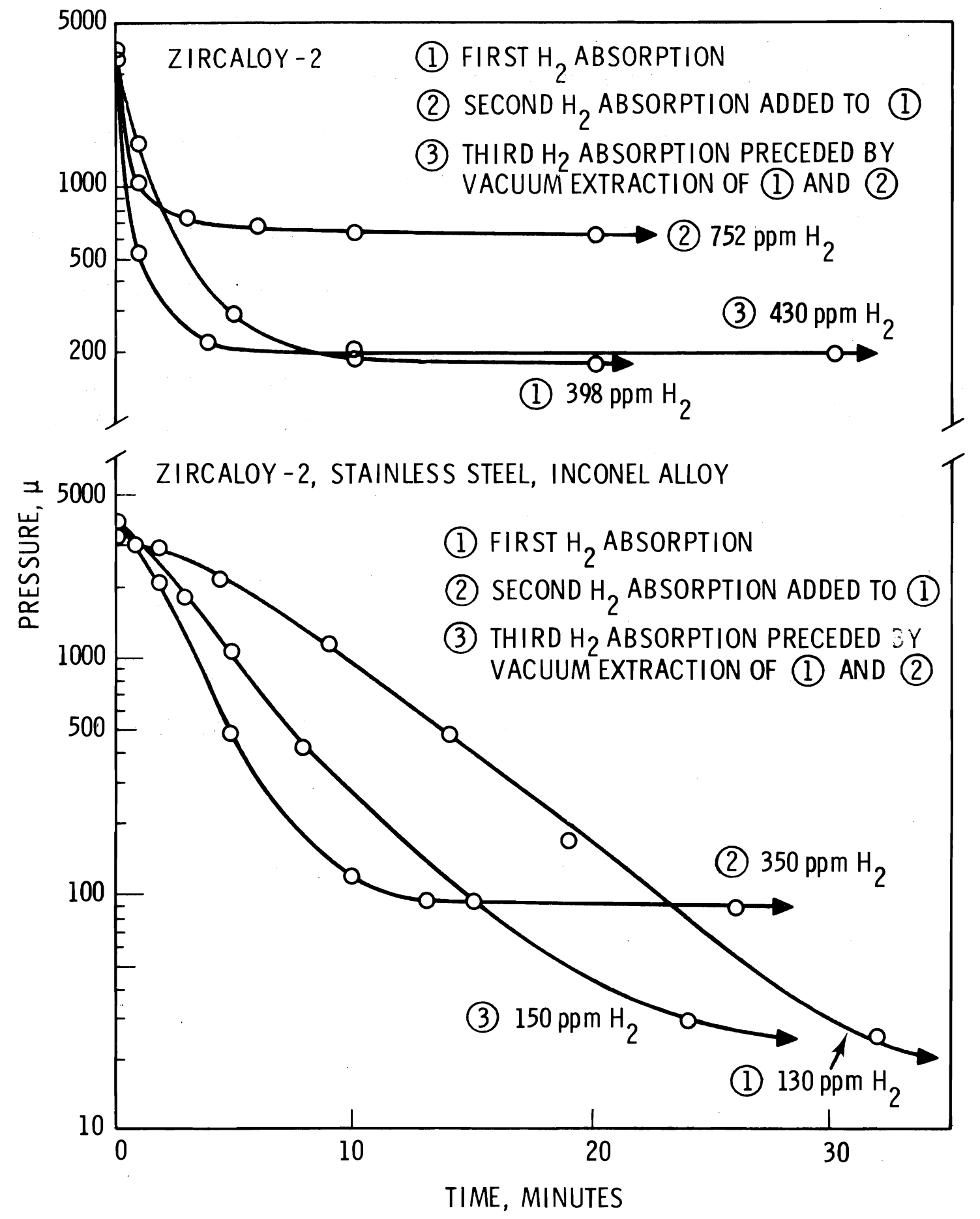

FIGURE 13. Hydrogen Pressure Versus Time at $700^{\circ} \mathrm{C}(16)$ 


\section{FUTURE WORK}

Future work will be aimed at the following:
a) Determine the effectiveness of the graphite crucible eutectic process in melting ozidized material.
b) Determine mechanical and corrosion properties of the cast materials.
C) Improve the Inductoslag melting rate of $\mathrm{Zr}$, stainless steel, Inconel alloys.
d) Melt small samples of irradiated material and determine the extent and mechanism of decontamination, and the effect of the $\mathrm{CaF}_{2}$ and $\mathrm{CaF}_{2}-\mathrm{MgF}_{2}$ slags on TRU levels.
e) Cold mock-up of Inductoslag melting.
f) In-cell operation of the Inductoslag melting process.
g) Seek reuse applications in nuclear facilities.
h) Monitor and compare the economic feasibility of this waste treatment process with other proposed waste treatment methods. 


\section{REFERENCES}

1. B. Griggs, Feasibility Studies for Decontamination and Densification of Chop-Leach Cladding Residues, BNWL-1820, JuTy 1974.

2. D. S. Webster, A. A. Jonke, N. M. Levitz, W. E. Miller, M. J. Steindler, and R. C. Vogel, Fuel Cycle Technology Quarterly Report, AN:-7972, p. 46, December 1972.

3. L. M. Grossman and J. 0. Hegland, Tritium Distribution in High Power Zircaloy Fuel Elements, GEAP-12205, June 1971.

4. F. H. Megerth, C. P. Ruiz and U. E. Wolff, Zircaloy-Clad U02 Fuel Rod Evaluation Program, Final Report, GEAP-10371, pp. 88-96, June 1971.

5. F. H. Megerth, C. P. Ruiz and U. E. Wolff, ibid, p. 110.

6. Siting of Fuel Reprocessing Plants and Waste Management Facilities, ORNL-4457, pp. 3-23, JuTy 1970.

7. J. 0. Blomeke and J. J. Perons, Storage, Shipment and Disposal of Spent Fuel Cladding, ORNL-TM-3650, January 1972.

8. Reprocessing of Dresden Reactor Fuel at Nuclear Fuel Services, West Valley Facility, SRO-123, pp. 50-53, October 1968.

9. A. M. Platt, Nuclear Waste Management and Transportation Quarterly Progress Report, July through September 1975, BNWL-1952, Battelle, Pacific Northwest Laboratories, Richland, WA, pp. 14-29, November 1975.

10. G. J. Dau, Nuclear Waste Management and Transportation Quarterly Progress Report, October through December 1974, BNWL-1899, Batte11e, Pacific Northwest Laboratories, Richland, WA, pp. 29-40, February 1975.

11. A. B. Meservey, "Decontamination and Film Removal," Decontamination of Nuclear Reactors and Equipment, J. A. Ayres, Editor, Ronald Press, NY, pp. 147-149, 1970.

12. B. Lustman and F. Kerze, Jr., The Metallurgy of Zirconium, McGraw-Hi11, NY, pp. 236, 450, 1955.

13. R. G. Nelson, M. P. Schlienger and E. V. Tiesenhausen, Selection of a Melting Furnace for Consolidation of Nuclear Fuel Hul1s, BNWL-1968, Battelle, Pacific Northwest Laboratories, Richland, WA, (To be Published).

14. P. G. Clites and R. A. Beall, "Inductoslag Melting of Titanium Scrap and Sponge," Proceedings of Sessions 101st AIME Annual Meeting, San Francisco, CA, February 20-24, 1972, Light Metals, W. C. Rotse11, Editor, 1972. 
15. P. G. Clites and R. A. Beal1, "Preparation of Ingots and Shaped Castings by Inductoslag Melting," Proceedings of the Fifth International Symposium on Electroslag and Other Special Melting Technologies, Part II, Pittsburgh, PA, October 16-18, 1974, G. H. Bhat and A. Simkovich, Editors, pp. 477-496, 1974.

16. A. M. Platt, Nuclear Waste Management and Transportation Quarterly Progress Report, January through March 1975, BNWL-1913, Battelle, Pacific Northwest Laboratories, Richland, WA, pp. 28-33, June 1975.

17. A. M. Platt, Nuclear Waste Management and Transportation Quarterly Progress Report, October through December 1975, BNWL-1978, Battelle, Pacific Northwest Laboratories, Richland, WA, pp. 17-22, April 1976.

18. A. M. Platt, Nuclear Waste Management and Transportation Quarterly Progress Report, January through March 1976, Battelle, Pacific Northwest Laboratories, Richland, WA, (To be Published).

19. Metals Handbook, 8th Edition, American Society for Metals, Metal Park, OH, pp. 293, 308, 327, 1973.

20. K. J. Schneider, Compiler, Quarterly Progress Report Studies on Management of Selected Wastes, January through March 1974, BNWL-1825, Battelle, Pacific Northwest Laboratories, Richland, WA, pp. 3-18, April 1974.

21. G. J. Dau, Nuclear Waste Management and Transportation Quarterly Progress Report, July through September 1974, BNWL-1876, Batte17e, Pacific Northwest Laboratories, Richland, WA, pp. 49-58, November 1974. 


\section{ACKNOWLEDGMENTS}

The progress of this program has been greatly enhanced by the technical consultation and Inductoslag melting services performed by P. G. Clites, R. A. Beal1 and staff of the United States Bureau of Mines, Albany, Oregon. 


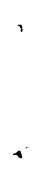




\section{DISTRIBUTION}

No. of

Copies

\section{$\underline{\text { OFFSITE }}$}

\section{UNITED STATES}

A. A. Churm

ERDA Chicago Patent Group

9800 South Cass Avenue

Argonne, IL 60439

S. H. Smiley

Deputy Director for

Fuels and Materials

NRC Directorate of Licensing

for Fuels and Materials

4915 St. Elmo Ave.

Bethesda, MD 20014

R. B. Chitwood

Chief, Technical Support Branch for Fuels and Materials

NRC Directorate of Licensing

for Fuels and Materials

4915 St. Elmo Ave.

Bethesda, MD 20014

W. P. Bishop

Chief, Waste Management Branch

NRC Division of Materials and

Fuel Cycle Facility Licensing Washington, DC 20555

W. G. Belter

ERDA Division of Biomedical and Environmental Research

Earth Sciences Branch

Washington, DC 20545

H. Glauberman

ERDA Division of Environmental

Control Technology

Washington, DC 20545

H. Hollister

ERDA Division of Environmental

Control Technology

Washington, DC 20545
No. of

Copies

M. S. Kearney

ERDA Division of Environmental

Control Technology

Washington, DC 20545

W. E. Mott

ERDA Division of Environmental

Control Technology

Washington, DC 20545

F. P. Baranowski

ERDA Division of Nuclear Fuel

Cycle and Production

Washington, DC 20545

E. E. Sinclair

Assistant Director for

Reactor Technology

ERDA Division of Reactor

Research and Development

Washington, DC 20545

W. H. McVey

Chief, Fuel Recycle Branch

ERDA Division of Reactor

Research and Development

Washington, DC 20545

K. K. Kennedy

ERDA Idaho Operations Office

P.0. Box 2108

Idaho Falls, ID 83401

W. F. Hendrickson

ERDA Idaho Operations Office

P.0. Box 2108

Idaho Falls, ID 83401

E. H. Hardison

ERDA Oak Ridge Operations Office

P.0. Box X

Oak Ridge, TN 37830

0. T. Turmelle

ERDA Oak Ridge Operations Office

P.0. Box $X$

Oak Ridge, TN 37830 
No. of

Copies

R. L. Chandler

ERDA Savannah River Operations office

P.0. Box A

Aiken, SC 29801

246 ERDA Technical Information Center

J. A. Buckham

Allied Chemical Corporation

550 - 2nd Street

Idaho Falls, ID 83401

B. C. Musgrave

Allied Chemical Corporation

550 - 2nd Street

Idaho Falls, ID 83401

C. M. Slansky

Allied Chemical Corporation

550 - 2nd Street

Idaho Falls, ID 83401

A. Schneider

Allied-General Nuclear Services

P.0. Box 847

Barnwel1, SC 29812

N. M. Levitz

Argonne National Laboratory 9700 South Cass Ave.

Argonne, IL 60439

M. J. Steindler/

L. E. Trevorrow

Argonne National Laboratory 9700 South Cass Ave.

Argonne, IL 60439

E. S. Bartlett

Battelle Memorial Institute 505 King Ave.

Columbus, $\mathrm{OH} 43201$
No. of

Copies

J. J. Reilly

Brookhaven National Laboratory

Research Library,

Reference Section

Information Division

Upton, Long Island, NY 11973

R. H. Wiswall

Brookhaven National Laboratory

Research Library,

Reference Section

Information Division

Upton, Long Island, NY 11973

Chaim Braun

Brookhaven National Laboratory

Energy Systems Library

Building 902

Upton, NY 11973

Combustion Division

Combustion Engineering, Inc.

Windsor, CT 06095

M. A. Thompson

Dow Chemical Company (ERDA)

Rocky Flats Division

P.0. Box 888

Golden, C0 80401

D. L. Ziegler

Dow Chemical Company (ERDA)

Rocky Flats Division

P.0. Box 888

Golden, CO 80401

C. H. Ice

duPont Company, Aiken (ERDA)

E. I. duPont DeNemours and Co.

Savannah River Laboratory

Aiken, SC 29801

A. S. Jennings

duPont Company, Aiken (ERDA)

Savannah River Laboratory

Aiken, SC 29801 
No. of

Copies
No. of

Copies

A. A. Johnson

dePont Company, Wilmington (ERDA)

E. I. duPont DeNemours and Co.

Wilmington, DE 19898

L. Henning

Electric Power Research Institute 3412 Hillview Ave.

P.0. Box 10412

Palo Alto, CA 94304

M. Levenson

Electric Power Research Institute

3412 Hillview Ave.

P.0. Box 10412

Palo Alto, CA 94304

E. Zebroski

Electric Power Research Institute 3412 Hillview Ave.

P.0. Box 10412

Palo Alto, CA 94304

G. L. Meyer

Environmental Protection Agency

Technology Assessment Div. (AW-559)

Office of Radiation Programs

U.S. Environmental Protection Agency

Washington, DC 20460

B. Mann

Environmental Protection Agency

P.0. Box 15027

Las Vegas, NV 89114

R. E. Landreth

Environmental Protection Agency

5555 Ridge Ave.

Cincinnati, $\mathrm{OH} 45213$

R. G. Barries

General Electric Company

175 Curtner Ave.

(M/C 160)

San Jose, CA 95125
E. E. Voiland

General Electric Company

Midwest Fuel Recovery Plant

Route 1, Box 219-B

Morris, IL 60450

W. H. Reas

General Electric Company

Vallecitos Nuclear Center

Vallecitos Road

Pleasanton, CA 94566

L. H. Brooks

Gulf Energy and Environmental Systems

P.0. Box 81608

San Diego, CA 92138

4 Oak Ridge National Laboratory

Central Research Library Document Reference Section

Oak Ridge, TN 37830

C. W. Christenson

Los Alamos Scientific Laboratory (ERDA)

P.0. Box 1663

Los Alamos, NM 87544

L. J. Johnson

Los Alamos Scientific Laboratory (ERDA).

P.0. Box 1663

Los Alamos, NM 87544

H. S. Jordan

Los Alamos Scientific Laboratory (ERDA)

P.0. Box 1663

Los Alamos, NM 87544

C. J. Kershner

Monsanto Research Corporation Mound Laboratory

P.0. Box 32

Miamisburg, $\mathrm{OH} 45342$ 
No. of

Copies

P. Lamberger

Monsanto Research Corporation Mound Laboratory

P.0. Box 32

Miamisburg, OH 45342

Stephen Brown

National Lead Company

111 Broadway

New York, NY 10006

D. Cyrus $\mathrm{K} 1$ ingsberg, Technical Secretary

National Academy of Sciences

Committee of Radioactive Waste Management

National Research Council

2101 Constitution Avenue

Washington, DC 20418

T. Lash

Natural Resources Defense Council, Inc.

664 Hamilton Avenue

Palo Alto, CA 94301

J. P. Duckworth, Plant Manager

Nuclear Fuel Services, Inc. P.0. Box 124

West Valley, NY 14171

E. D. North, Director of Technical Administration Nuclear Fuel Services, Inc. 6000 Executive Blvd., Suite 600 Rockville, MD 20852

W. L. Pearl

Nuclear Water and Waste Technology, Inc.

P.0. Box 6406

San Jose, CA 95150

J. G. Cline, General Manager NYS Atomic and Space Development Authority

230 Park Avenue, Rm. 2425

New York, NY 10017
No. of

Copies

Frank von Hippel

Princeton University Center for Environmental Studies, Engineering School

Princeton, NJ 08540

J. Sivinski

Sandia Laboratories

A1buquerque, NM 87107

W. Weart

Sandia Laboratories

Albuquerque, NM 87107

B. R. Teer

Transnuclear, Inc.

One North Broadway

White Plains, NY 10601

J. 0. Blomeke

Union Carbide Corporation (ORNL)

Chemical Technology Division

P.0. Box Y

Oak Ridge, TN 37830

D. E. Ferguson

Union Carbide Corporation (ORNL)

Chemical Technology Division

P.0. Box $Y$

Oak Ridge, TN 37830

E. H. Kobisk

Union Carbide Corporation (ORNL)

Chemical Technology Division

P.0. Box Y

Oak Ridge, TN 37830

K. H. Lin

Union Carbide Corporation (ORNL)

Chemical Technology Division

P.0. Box $Y$

Oak Ridge, TN 37830

W. C. McClain

Union Carbide Corporation (ORNL)

Chemical Technology Division

P.0. Box $Y$

Oak Ridge, TN 37830 
No. of

$\underline{\text { Copies }}$

W. C. UTrich

Union Carbide Corporation (ORNL)

Chemical Technology Division

P.0. Box $Y$

Oak Ridge, TN 37830

S. E. Logan

University of New Mexico

Albuquerque, NM 87131

R. A. Beal1

U.S. Department of Interior

Bureau of Mines

Albany Research Center

1450 W. Queen Avenue

Albany, OR 97321

\section{FOREIGN}

Rene Amavis

EURATOM

Health Physics Division

29, Rue Aldringer

Luxembourg, BELGIUM

K. D. B. Johnson

Atomic Energy Research

Establishment

Harwe11, Didcot,

Berks, ENGLAND

D. W. Clelland

United Kingdom Atomic Energy Authority

Risley, ENGLAND

R. Bonniaud

Centre de Marcoule

B. P. 106

30 - Bagnols S/Ceze

FRANCE

P. J. Regnaut

Centre d'Etudes Nucleaires de Fontenay-aux-Roses

Boite Postale 6

92 - Fontenay-aux-Roses

FRANCE
No. of

Copies

J. Sauteron

Centre d'Etudes Nucleaires de Fontenay-aux-Roses

Boite Postale 6

92 - Fontenay-aux-Roses

FRANCE

Y. J. Sousselier

Centre d'Etudes Nucleaires de Fontenay-aux-Roses

Boite Postale 6

92 - Fontenay-aux-Roses

FRANCE

Bundesministerium für Forschung und Technologie

Stresemannstrasse 2

5300 Bonn

GERMANY

Han-Meitner-Institut

(Hans W. Levi)

für Kernforschung Berlin (HMI)

Glienicker Strasse 100

1000 Berlin 39

GERMANY

3 KFA-Kernforschungsanlage Jülich $\mathrm{GmbH}$

Postfach 1913

5170 Jülich 1

GERMANY

Gesellschaft für

Wiederaufarbeitung von

Kernbrennstoffen mbH (GWK)

7501 Leopoldshafen .

GERMANY

Gesel1schaft für Kernforschung (GfK)

Postfach 3640

7500 Karlsruhe

GERMANY 
No. of

Copies

$\mathrm{Fa}$.

NUKEM BmbH (Dr. Hartmut Witte)

Postfach 110080

6450 Hanau 11

WEST GERMANY

Giacomo Calleri

CNEN

Directtore di Programma

Eurex Del CNEN

Saluggia "Vercel1i", ITALY

Willy Bocola

Laboratorio di Ingegneria

Sanitaria

Via Anguillarese km $1+300$

Roma, ITALY

Ferruccio Gera Laboratorio Rifiuti Radioacttivi

C.N.E.N. - C.S.N. Casaccia

Casella Postale 2400

00100 Rome, ITALY

N. S. Sunder Rajan

Bhabha Atomic Research Centre

Waste Treatment Division

Trombay, Bombay, INDIA

K. T. Thomas

Bhabha Atomic Research Centre Waste Treatment Division

Trombay, Bombay, INDIA

R. V. Amalraj

C.W.M.F. Project

P.0. Kalpakkam

Chingleput Dist.

Tamil Nadu, INDIA

International Atomic Energy Agency

Kärtner Ring 11

P.0. Box 590

A-1011, Vienna, AUSTRIA
No. of

Copies

Fa.

Friedrich Uhde GmbH

(Dr. H. F. Ramdohr)

Deggingstrasse 10-12

4600 Dortmund

GERMANY

\section{ONSITE}

6 ERDA Richland Operations Office

0. J. Elgert

R. B. Goranson

N. T. Karagianes

R. D. Fogerson

D. J. Squires

F. R. Standerfer

7 Atlantic Richfield Hanford Company

D. R. Gustafson

R. E. Isaacson

D. C. Nelson

A. E. Smith/M. J. Szulinski

J. H. Warren

D. D. Wodrich

File Copy

1 Exxon Nuclear Co., Inc.

S. J. Beard

1 Joint Center for Graduate Study

J. Cooper

3 United Nuclear Industries, Inc.

A. P. Larrick

2 Westinghouse Hanford Company

A. G. Blasewitz

C. R. Cooley 
No. of

Copies

69 Battelle-Northwest

T. W. Ambrose

J. W. Bartlett

R. J. Bashor

C. L. Brown

L. L. Burger

H. C. Burkholder

N. E. Carter

M. 0. Cloninger

G. J. Dau

R. L. Dillon

J. R. Eliason

J. W. Finnigan

J. C. Fox

J. J. Fuquay

B. Griggs(12)

A. J. Haverfield

E. V. Irish

J. H. Jarrett

R. S. Kemper

M. R. Kreiter

K. M. Harmon

R. C. Liikala

R. P. Marsha11/R. W. Stewart

J. L. McElroy

L. K. Mudge

R. G. Nelson (12)

J. M. Nielsen/R. W. Perkins

R. E. Nightingale

D. E. Olesen

L. T. Pedersen

A. M. Platt

J. A. Powe 11

K. J. Schneider

C. L. Simpson/C. E. Elderkin

B. E. Vaughan/W. L. Templeton

P. C. Walkup

E. J. Wheelwright

W. R. Wiley

L. D. Williams

W. K. Winegardner

H. H. Van Tuyl

Technical Information (5)

Technical Publications 
